\title{
Do Multiple Loans from Microfinance Institutions Help the Rural Poor Women? Empirical Evidence from
} Ghana

\author{
Samuel Erasmus Alnaa, ${ }^{1, *}$ \\ ${ }^{1}$ Department of Accountancy, Bolgatanga Polytechnic, P.O. Box 767, Bolgatanga, Ghana \\ *Correspondence: Tel: 233-242-803-715 E-mail: sam.alnaa@gmail.com \\ Received: June 20, 2013 \\ Accepted: July 30, 2013 Published: August 26, 2013 \\ doi:10.5296/rae.v5i3.3874 \\ URL: http://dx.doi.org/10.5296/rae.v5i3.3874
}

\begin{abstract}
The theory on microfinance reveals that continued access to credit and the process of increased investment increases income further thereby enabling the borrower to gradually climb out of poverty. In consonance with this, the main objective of this study was to verify if multiple loans from microfinance institutions help the rural poor women in the Upper East Region of Ghana to reduce household poverty, using treatment effect method of estimation. In pursuance of this, data was collected from 500 women engaged in agro-processing of whom 250 were beneficiaries of multiple loans and 250 non-beneficiaries.

The results showed that respondents from the Bawku West district were less likely to receive multiple loans than their counterparts from the Bongo, Builsa and Talensi-Nabdan districts. Also respondents with post secondary education were less likely to receive multiple loans than those with no formal education. Again, respondents who received loans at least three and four times, had higher weekly consumption expenditure on basic needs than those who received loans at most two and three times respectively. The results further showed spatial differences in consumption expenditures with Kasena Nankana and Bawku West districts spending more on basic needs per week than respondents from Bongo, Talensi-Nabdan and the Builsa districts. An increase in the number of dependents also increases weekly consumption expenditure.
\end{abstract}

By implication, multiple loans from microfinance institutions contribute positively to reducing household poverty among rural women engaged in agro-processing in the Upper East Region.

In the light of this, it is recommended that microfinance institutions should lend out to clients as many times as possible in the Upper East Region as long as these clients are able to repay since it has a positive impact on poverty reduction.

JEL Classification: C1, D13, D14, G21

Keywords: poverty; multiple loans; rural women; treatment effect estimation and Ghana 


\section{Introduction}

Microfinance is hailed by many as an important tool for poverty alleviation. This is so for a number of reasons. Microfinance allows poor people to protect, diversify, and increase their sources of income, this it is believed is the essential path out of poverty and hunger. The ability to borrow a small amount of money to take advantage of a business opportunity, to pay for school fees, or to bridge a cash-flow gap, can be a first step in breaking the vicious cycle of poverty (Littlefield, Murduch \& Hashemi, 2003).

Similarly, poor households will use a safe, convenient savings account to accumulate enough cash to buy assets such as inventory for a small business enterprise, to fix a leaky roof, to pay for health care, or to send more children to school (Littlefield, Murduch \& Hashemi, 2003). It is again observed that microfinance helps safeguard poor households against the extreme vulnerability that characterizes their everyday existence. Loans, savings, and insurance help smoothen out income fluctuations and maintain consumption levels even during the lean periods. The availability of financial services acts as a buffer for sudden emergencies, business risks, seasonal slumps, or events such as a flood or a death in the family that can push a poor family into destitution (Littlefield, Murduch \& Hashemi, 2003).

Marguerite (2001) observed that among the economically active poor of the developing world, there is strong demand for small scale commercial financial services-for both credit and savings. Where available, these and other financial services help low income people improve household and enterprise management, increase productivity, smoothen income flows and consumption cost, enlarge and diversify their micro business and increase their incomes.

Microfinance can be used as an effective method of poverty alleviation for the poorest people. It is however indicated that the solution for providing micro-financial services to the very poor is to design programmes that suit the needs of destitute families (Marcus, Porter \& Harper, 1999).

According to Navajas et al. (2000), the professed goal of microcredit is to improve the welfare of the poor due to better access to small loans. Diagne and Zeller (2001) argued that, lack of adequate access to credit for the poor can have negative consequences for various household level outcomes including technology adoption, agricultural productivity, food security, nutrition, health and overall welfare. Access to credit therefore affects welfare outcomes by alleviating the capital constraints on agricultural households, hence enabling poor households with little or no savings to acquire agricultural inputs (Okurut, Banga \& Mukungu 2004).

Proponents of microfinance programmes therefore believe that access to small loans creates a virtuous cycle of investment and increases income which can break the vicious cycle of poverty in which many poor people are trapped. It has been argued that the infusion of credit creates opportunities for self-employment for poor borrowers and that this in turn augments their income and leads to increased consumption and investment. Continued access to credit and the process of increased investment increases income yet further (Khan, 2008). This theory suggested that as this cycle is continually repeated with successive loans the poor 
borrower will gradually climb out of poverty (Khan, 2008).

Scores of studies have found positive impact of microfinance on poverty and other household welfare outcomes (e.g. Remenyi \& Quinones, 2000; Morduch \& Haley, 2002; Khandker, 2005; Gobezie \& Garber, 2007; Imai \& Azam, 2010; Imai, Arun \& Annim, 2010; Ghalib, Malki \& Imai, 2011; Annim \& Alnaa, 2013). Though various studies have pointed to this fact, some of the findings have been contested and have pointed to the contrary (e.g. Banerjee et al., 2010; Karlan \& Zinman, 2009; Feigenberg et al., 2010).

The Ghana Statistical Service (GSS) (2008) has indicated that poverty in Ghana is disproportionately a rural phenomenon and that $86 \%$ of the total population who live below the poverty line in Ghana, reside in rural areas. A report by IFAD (2009) indicated that, in Ghana more than half of the women who are heads of households in rural areas are among the poorest 20 per cent of the population and that women are responsible for 55 to 60 per cent of agricultural production. Against this background, concerted efforts have been made at fighting poverty. These efforts can be seen particularly with the implementation of the (Growth and Poverty Reduction Strategy (GPRS I \& II) which represent comprehensive policies to support growth and poverty reduction. Again various Microfinance programmes have been implemented.

The financial sector reforms in Ghana gave an impetus to the Microfinance industry in Ghana to grow. This was to meet the ever increasing financial needs of poor households who are usually unreached and underserved by the microfinance institutions. In sub-Saharan Africa (SSA), as at 2007, Ghana was ranked the highest recipient (about US\$186m) of development partner's donor funding into microfinance (CGAP, 2008). Thus over the years, the poor have had increasing access to credit particularly rural women with some of these women having the opportunity to gain access to multiple loans or repeated credit.

In a similar vein the Upper East Region which is the second poorest Region in the country with about $70 \%$ of the population living below the poverty line (GSS, 2008), received massive MFIs activities targeting rural poor women. With more than 37 microfinance institutions(Note 1) dotted across the length and breadth of the Region, most of the beneficiary women have accessed multiple loans from these microfinance institutions. Most of these women engage in agro-processing activities such as rice milling, shea-butter extraction, malt making, etc. These loans from the microfinance institutions were meant to help these women boost their output, increase their earnings and ultimately improve upon their socio-economic welfare.

Akpalu, Alnaa and Aglobitse (2012) have indicated that microfinance has positive impact on the technical efficiency of women engaged in agro-processing in the Upper East Region and that this has the tendency of positively affecting their welfare outcomes. However to the best of our knowledge studies on the impact of multiple loans or repeated credit on the welfare outcomes of rural poor women in the Region is lacking.

Anecdotal reports on this subject matter are conflicting. The contentions are that, these multiple times borrowers simply borrow from one microfinance institution only to use the 
amount borrowed to repay an old loan contracted elsewhere and that such practices only worsen the welfare of the borrowers thus leading to a microfinance dependency syndrome. Another school of thought contends that it is the best performing clients that have the opportunity to borrow multiple times. Again that since these category of clients borrow multiple times from microfinance institutions they have the opportunity to benefit from other services provided by such microfinance institutions such as training, and that this enhances the business performance of the clients which is ultimately translated into increased welfare outcomes. Thus, this study is intended to set the records straight on these apparent contestations. In the light of these, the broader objective of the study is to determine if multiple loans from microfinance institutions help the rural poor women in reducing household poverty.

\section{Method and Data}

The study employed a quasi-experimental survey. Thus the data for the study was obtained from both beneficiaries (treatment group) and non-beneficiaries (control group) of MFI loans in 2011 through a random survey of 500 women engaged in agro-processing in the Upper East Region of Ghana, of whom 250 were beneficiaries of microfinance while 250 were non-beneficiaries. Interview schedules were administered to the randomly selected respondents in a face-to-face interview. The questions included in the interview related to access to microfinance, initial savings, consumption expenditure on basic needs, the number of times one has taken loans from microfinance institution(s), the number of business activities the woman engages in at the moment, the location of the business, and several other socio-demographic characteristics.

\subsection{Model Specification}

The treatment effect model is used here, following Greene (2003, pp. 787-789); Heckman and Vytlacil (2005); Imai, Arun and Annim (2010); Annim \& Alnaa (2013)

Let;

$$
C=f\left(\pi, R_{1}, \eta, D_{i}, \Omega\right)
$$

Where; $C=$ consumption expenditure, $\pi=$ profit of the respondent, $R_{1}=$ initial financial resources of the respondent, $\eta=$ vector of household characteristics, $D_{i}=$ District level dummies (vibrant market centres, 1 if district has a vibrant market centre, otherwise 0) and $\Omega=$ number of times one has received loans from MFI (multiple loans), measured as a binary variable; 1 if the respondent has received loan three times or more, otherwise 0 .

Again let;

$$
X=\pi, R_{1}, \eta, D_{i}
$$


Write potential outcomes $C_{1} \mid X, \Omega$ and $C_{0} \mid X$ as:

$$
\begin{aligned}
& C_{1}=X^{\prime} \beta_{i}+\Delta \Omega_{1}+\varepsilon_{1} \\
& C_{0}=X^{\prime} \beta_{i}+\Delta \Omega_{0}+\varepsilon_{0}
\end{aligned}
$$

but $\Delta \Omega_{0}=0$

Where $C_{1}$ is the outcome for those who have received loans three times or more and $C_{0}$ is the outcome for those who have received loan less than three times, such that both $C_{1}$ and $C_{0}$ are observed. Equations (3) and (4) can be compactly stated as:

$$
C_{j}=X^{\prime} \beta_{i}+\Delta \Omega_{j}+\varepsilon_{j}
$$

Where $j=1$ if respondent has received loans three times or more and $j=0$ if respondent has received loan less than three times, while $\Delta$ measures the average value of consumption expenditure on basic needs due to multiple loans $(\Omega)$ and $\beta_{i}$ are unknown parameters to be estimated. However, there are unobservable factors or characteristics that influence individuals to self-select to either borrow multiple loans from an MFI or otherwise $(\Omega)$. These unobserved factors are therefore captured by the residual term $\left(\varepsilon_{j}\right)$. If this happens then $\Omega$ and $\varepsilon_{j}$ are correlated, thus raising the issues of selection bias. If the problem is one of selection bias, then Ordinary Least Squares (OLS) estimates of equation (5) will actually bias the estimate of $(\Delta)$. In the light of this, the Treatment effects model which is one of the methods of solving the selection bias is employed here. The basic idea behind these models is to estimate two regressions simultaneously.

The first is a probit regression predicting the probability of treatment $(\Omega)$. The second is a linear regression for the outcome of interest $\left(C_{i}\right)$ as a function of the "treatment" variable, controlling for observable confounders.

$$
\Omega_{i}=H_{i}^{\prime} \gamma+\mu
$$

but $\mathrm{H}_{i}=X+I V$

That is, $H_{i}$ which are the variables determining receiving loans three times or more contain all the elements in $X$ plus at least an additional (element; instrumental variable $(I V)$ ) not in $X$. This satisfies the exclusion restriction requirement.

$\operatorname{But} \operatorname{corr}(\Omega, \varepsilon) \neq 0$ 
It is assumed that the error terms ( $\varepsilon$ and $\mu$ ) are jointly normally distributed and a maximum

likelihood methods of estimation was used. Because $\operatorname{corr}(\Omega, \varepsilon) \neq 0$ then appropriate Instrumental Variable(s) (IV) must be found to solve the problem. In which case $I V$ must be correlated with $\Omega_{i}$ but not correlated with $C_{i}$.

Thus, the expected consumption expenditure for those who have received MFIs loans three times or more is given by the joint density bivariate normally distributed variables and of the formula:

$$
E\left[C_{i} \mid \Omega_{i}=1\right]=\beta^{\prime} X_{i}+\Delta+E\left[\varepsilon \mid \Omega_{i}=1\right]=\beta^{\prime} X_{i}+\Delta+\rho \sigma_{\varepsilon} \frac{\phi\left(\gamma^{\prime} h_{i}\right)}{\Phi\left(\gamma^{\prime} h_{i}\right)}
$$

Where, $\phi$ is the standard normal density function and $\Phi$ is the standard normal cumulative distribution function. The ratio of $\phi$ and $\Phi$ is called the inverse Mill's ratio (IMR) (sometimes also called 'selection hazard' particularly in the treatment effect model) or control functions and it takes account of possible selection bias. When the coefficient of IMR is positive there are unobserved variables that both increase the probability of selection and a higher than average score on the dependent variable. When the coefficient of IMR is negative there are unobserved variables increasing the probability of selection and the probability of a lower than average score on the dependent variable. The expected consumption expenditure for those who have received loans less than three times is given as:

$$
E\left[C_{i} \mid \Omega_{i}=0\right]=\beta^{\prime} X_{i}+E\left[\varepsilon \mid \Omega_{i}=0\right]=\beta^{\prime} X_{i}-\rho \sigma_{\varepsilon} \frac{\phi\left(\gamma^{\prime} h_{i}\right)}{1-\Phi\left(\gamma^{\prime} h_{i}\right)}
$$

The expected effect of poverty reduction as a result of multiple borrowing (loans) can be calculated as:

$$
E\left[C_{i} \mid \Omega_{i}=1\right]-E\left[C_{i} \mid \Omega_{i}=0\right]=\Delta+\rho \sigma_{\varepsilon} \frac{\phi\left(\gamma^{\prime} h_{i}\right)}{\Phi\left(\gamma^{\prime} h_{i}\right)\left[1-\Phi\left(\gamma^{\prime} h_{i}\right)\right]}
$$

If $\rho$ is positive (negative), then the coefficient estimate of $\Delta$ employing the method of OLS will be biased upwards (downwards), but the sample selection term (inverse mills ratio) will correct for this (Imai, Arun and Annim, 2010). The sign and significance of the estimate of $\rho \sigma_{\varepsilon}(\lambda)$ shows if selection bias exists. 


\subsection{Empirical Model}

$$
\begin{aligned}
& w k \text { expend }=\beta_{0}+\beta_{1} \text { hhppl }+\beta_{2} \text { depend }+\beta_{3} \text { oldsav }+\beta_{4} \text { amtprof }+\beta_{5} \text { numacty }+ \\
& \beta_{6} \text { lonsours }+\beta_{7} \text { hhppbor }+\beta_{8} \text { age }+\beta_{9} \text { age } 1+\beta_{10} \text { assets }+\beta_{11} \text { kasena }+ \\
& \beta_{12} \text { bwest }+D_{i} \text { edulev }+\varepsilon \\
& \text { mfmany }=\gamma_{0}+\gamma_{1} h h p p l+\gamma_{2} \text { depend }+\gamma_{3} \text { oldsav }+\gamma_{4} \text { amtprof }+\gamma_{5} \text { numacty }+ \\
& \gamma_{6} \text { lonsours }+\gamma_{7} \text { hhppbor }+\gamma_{8} \text { age }+\gamma_{9} \text { age } 1+\gamma_{10} \text { assets }+\gamma_{11} \text { kasena }+ \\
& \gamma_{12} \text { bwest }+\gamma_{13} \text { frnsours }+D_{i} \text { edulev }+\mu
\end{aligned}
$$

Where mfmany denotes the number times one has received a loan from an MFI and frnsours is the number of friends who have ever borrowed from an MFI is an instrument for mfmany the rest of the variables are as defined in Table 1 . Thus both equations (10) and (11) were estimated together using the treatment effect estimation technique.

\section{Results and Discussion}

This section presents the results as well as the discussion on the estimated impact of the number of times one has received a loan from an MFI using the treatment effect model. First the descriptive Statistics of Variables are presented, then the results of probability of one receiving a loan at least three times.

Table 1, shows the explanation and descriptive statistics of the data used for the analysis. Age, depend, edulev, numacty, lonsours, frnsours, kasena, bwest, builsa, Talensi, bongo and

hhppl are a set of household characteristics denoted by $\eta$ in the theoretical model. Where age is number of years of the respondent, the mean age is given as 39.95 or approximately 40 years. About $94 \%$ of the respondents are within the age brackets of 20-60 years and 69\% within the age group of 20-40 years. This suggests that majority of the respondents fall within the economically active group. The number of dependents in the respondent's household is denoted by depend with a mean number of three (3) dependents. Also, hhppl denotes the number of people in the respondent's household with a mean of about 7 people in each household. The variable frnsours denotes the number of friends of the respondent who have borrowed from an MFI. This measures the breadth of financial services in the community. Usually, the number of people in rural areas particularly the poor who are served by MFIs determine the breadth of financial services and as such the level of demand for the financial services. This variable is used as an instrumental variable for mfmany.

Also, lonsours measures the number of sources of borrowing that the respondent can actually borrow from within the community when in need of a loan. These sources include both formal (MFIs and Banks) and informal (friends, relatives and money lenders) institutions. Thus lonsours determines the number of these formal and informal financial institutions that the respondent can actually and confidently go to for a loan when in need. The amount of 
profit made in a month is denoted by amtprof $(\pi)$. The value of assets owned by the respondents measured in Cedis is denoted by assets. The variable oldsav $\left(R_{1}\right)$ measures the initial financial resources or savings of the respondent before receipt of loan from a MFI or start of agro-processing business.

Again, the variable numacty denotes the number of income generating activities that the respondent engages in as at the time of the study. wkexpend is the weekly consumption expenditure of the respondent on basic needs (food, clothes and rent) and this is denoted by $C$ in the model.

Table 1: Descriptive Statistics of Variables

\begin{tabular}{lllll}
\hline Variables & Description & Obs. & Mean & S.Deviation \\
\hline Poor1 & Poor (1/0) & 437 & 0.212 & 0.409 \\
Wkexpend & Weekly expenditure on basic needs & 437 & 25.00 & 13.615 \\
kasena & Kasena Nankana District (1/0) & 437 & 0.202 & 0.402 \\
bwest & Bawku west District (1/0) & 437 & 0.198 & 0.398 \\
builsa & Builsa District (1/0) & 437 & 0.198 & 0.40 \\
Talensi & Talensi/Nabdan District (1/0) & 437 & 0.202 & 0.402 \\
bongo & Bongo District(1/0) & 437 & 0.202 & 0.402 \\
age & Age in years & 437 & 39.951 & 11.659 \\
mfmany & Number of times received loans & 437 & 1.375 & 2.267 \\
depend & Dependants in household & 437 & 3.100 & 2.121 \\
frnsours & Number of friends with loans & 437 & 2.995 & 4.547 \\
hhppl & Number of people in household & 437 & 7.032 & 7.032 \\
hhppbor & Number of household people with loans & 437 & 0.302 & 0.606 \\
lonsours & Number of borrowing sources & 437 & 1.062 & 0.381 \\
amtprof & Amount of profit & 437 & 41.732 & 52.579 \\
numacty & Number of economic activities & 437 & 1.245 & 1.123 \\
oldsav & Initial savings & 457 & 98.993 & 133.701 \\
assets & Value of physical assets & 437 & 442.716 & 1040.845 \\
edulev & Educational level: & 437 & & \\
& No education (1/0) & & 0.531 & 0.500 \\
& Primary school(1/0) & & 0.245 & 0.430 \\
& JSS/Middle school(1/0) & & 0.151 & 0.358 \\
& SSS/Secondary school(1/0) & & 0.066 & 0.249 \\
\hline Source: Fien & Post Secondary school(1/0) & & & 0.0827 \\
\hline
\end{tabular}

Source: Field Survey data, (2011)

Kasena, bwest, builsa, talensi and bongo are district dummy variables for Kasena/Nankani, Bawku West, Builsa, Talensi/Nabdan and Bongo Districts respectively. The mean value for each of the Districts is given as 0.202, 0.198, 0.198, 0.202 and 0.202 respectively for Kasena/Nankani, Bawku West, Builsa, Talensi/Nabdan and Bongo Districts. This suggests that about $20 \%$ of the respondents are from each of the five Districts. However Kasena/Nankani and Bawku West districts have very vibrant market centres with high 
patronage from neighbouring country, i.e., Burkina Faso. Therefore the two spatial dummy variables are employed in the empirical model to capture the two major market areas. The remaining Districts; Builsa, Talensi/Nabdan and Bongo Districts which do not have vibrant market centres are used as the reference categories.

Also, the variable edulev is a categorical variable; it measures the highest educational level of the respondent. The mean of each level (category) of education shows the proportion (percentage) of the respondents in that category. Thus out of this variable, $53.1 \%$ have no education; 24.5\% have Primary school education; $15.1 \%$ have JSS/Middle school education; $6.6 \%$ have Senior Secondary School (SSS)/ secondary school education, while $0.7 \%$ have Post secondary school education. The no education is used as the reference category.

Table 2: Results of Probit Estimation of Receiving MFI loans at Least Three Times

\begin{tabular}{llcl}
\hline \multicolumn{1}{c}{ Variables } & \multicolumn{1}{c}{ Coefficient } & Std. error & P-Value \\
\hline Kasena Nankana District (1/0) & 0.072 & 0.205 & 0.724 \\
Bawku west District (1/0) & $-0.634^{* * *}$ & 0.225 & 0.005 \\
Age in years & $0.087^{*}$ & 0.045 & 0.068 \\
Age-squared & $-0.001^{*}$ & 0.001 & 0.087 \\
Dependants in household & 0.019 & 0.037 & 0.610 \\
Number of people in household & 0.017 & 0.025 & 0.513 \\
Number of borrowing sources & -0.122 & 0.205 & 0.553 \\
Number of friends with loans & $0.048^{* * *}$ & 0.015 & 0.001 \\
Amount of profit & $0.004^{* *}$ & 0.002 & 0.020 \\
No. of income generating activities & -0.052 & 0.077 & 0.499 \\
Initial savings & -0.0003 & 0.001 & 0.652 \\
Value of physical assets & -0.0001 & 0.0001 & 0.364 \\
Primary school(1/0) & $0.402^{* *}$ & 0.189 & 0.034 \\
JSS/Middle school(1/0) & $0.459^{* *}$ & 0.218 & 0.035 \\
SSS/Secondary school(1/0) & $0.566^{*}$ & 0.300 & 0.059 \\
Post Secondary school(1/0) & -8.546 & 0.000 & ------ \\
constant & $-3.046^{* * *}$ & 0.990 & 0.002 \\
Number of obs. & 437 & & \\
log likelihood & -203.086 & & \\
\hline
\end{tabular}

Source: Computed from field Survey data, (2011)

Note: *= significant at $10 \%$; **= significant at $5 \%$; ***=significant $1 \%$

Table 2 shows the results of probit model on the determinants of one receiving a loan at least three times from MFIs. The results show that Bawku west District and the number of friends with loans are all statistically different from zero at $1 \%$ significance level. Also Primary school, JSS/Middle school and amount of profit are statistically different from zero at 5\% significance level; however, SSS/Secondary school, age in years and age-squared are also statistically different from zero at $10 \%$ significance level. 
The coefficient of the Bawku west market variable is -0.634 . This suggests that respondents from the Bawku West District are less likely to receive a loan at least three times from MFIs than their counterparts from the Talensi-Nabdan, Bongo and Builsa Districts. The Bawku West District has less number of MFIs; there is only one rural Bank, one non-governmental financial organisation and now the microfinance and small loans centre. Thus it is possible that the loan portfolios of these MFIs are not large enough to serve the clients multiple times. Again the District has very vibrant market centres. It stands to reason therefore that, people from this District are able to make enough profit which they plough back into their business and would therefore not need to borrow three or more times from an MFI.

The number of friends of the respondent who have ever borrowed from an MFI also has a positive impact on the probability of borrowing at least three times from an MFI given its coefficient of 0.0482. As indicated earlier the number of friends of the respondent who have ever borrowed from an MFI measures the breadth of financial services in the community, thus as more rural poor people are served by the MFIs, the probability of those served encouraging their friends or peers to borrow multiple times from the MFIs increases.

The amount of profit respondents make in a month has positive impact on the probability of borrowing from an MFI. Thus as the amount of profit increases given the coefficient of 0.00396, the probability for one to take loans at least three times also increases. As one makes more profits from her business she is motivated after being able to pay for the previous loan, thus increasing the probability of her going in for a loan at least three times from the MFIs.

Again respondents with Primary school, JSS/Middle school and SSS/Secondary school education have higher probability of borrowing from an MFI at least three times than respondent with no education given their coefficients of $0.402,0.459$ and 0.566 respectively. It is possible that these category of respondents with some level of education are better able to manage their businesses well and are able to pay off their previous loans which entitles them to go for more loans.

The results also shows that the age of the respondent has a positive impact on the probability of one receiving a loan at least three times from an MFI given its coefficient of 0.0869 . However given the negative value of the coefficient of age-squared (-0.000940), it implies that the probability of one borrowing at least three times will decline after the respondent has attained the age of 46 years.

Table 3, shows the results of treatment effect estimation of impact of receiving MFI loans at least three times on log of weekly consumption expenditure. Thus the log of Weekly consumption expenditure (lwkexpend) is explained by Kasena Nankani District, Bawku West District, age, age-squared, received loan at least 3 times and dependants in household which are all statistically different from zero at $1 \%$ significance level. Also lwkexpend is explained by number of income generating activities and Primary school; these are statistically different from zero at 5\% significance level. Again amount of profit and Post Secondary school are also significant at $10 \%$ level. 
Table 3: Results of treatment effect estimation of impact of receiving MFI loans at least three times (dependent variable: log weekly consumption expenditure)

\begin{tabular}{llcc}
\hline \multicolumn{1}{c}{ Description } & Coefficient & Std. error & P-Value \\
\hline Kasena Nankana District (1/0) & $0.320^{* * *}$ & 0.072 & 0.000 \\
Bawku west District (1/0) & $0.604^{* * *}$ & 0.070 & 0.000 \\
Age in years & $0.047^{* * *}$ & 0.014 & 0.001 \\
Age-squared & $-0.001^{* * *}$ & 0.0002 & 0.001 \\
Dependants in household & $0.035^{* * *}$ & 0.013 & 0.007 \\
Number of people in household & -0.006 & 0.009 & 0.492 \\
Number of borrowing sources & -0.010 & 0.068 & 0.883 \\
Amount of profit & $0.001^{*}$ & 0.0006 & 0.051 \\
No. of income generating activities & $0.048^{* *}$ & 0.023 & 0.028 \\
Initial savings & 0.000 & 0.000 & 0.209 \\
Value of physical assets & 0.000 & 0.000 & 0.207 \\
Received loan at least 3 times(1/0) & $0.566^{* * *}$ & 0.199 & 0.005 \\
Primary school(1) & $0.137^{* *}$ & 0.069 & 0.049 \\
JSS/Middle school(2) & 0.106 & 0.082 & 0.194 \\
SSS/Secondary school(3) & -0.126 & 0.115 & 0.272 \\
Post Secondary school(4) & $0.509^{*}$ & 0.307 & 0.097 \\
constant & $1.451^{* * *}$ & 0.307 & 0.000 \\
Observations. & 437 & & \\
rho( $\rho$ ) & $-0.385^{*}$ & 0.206 & \\
sigma( $\sigma$ ) & $0.506^{* * *}$ & 0.026 & \\
Lambda $(\lambda)$ & $-0.195^{* * *}$ & 0.112 & \\
Wald chi2(16) & $204.67^{*}$ & & \\
Log likelihood & -509.646 & & \\
\hline
\end{tabular}

Source: Computed from field Survey data, (2011)

Note: Wald test of indep. eqns. $($ rho $=0): \chi^{2}$ (1) $2.82 *$

$*=$ significant at $10 \% ; * *=$ significant at $5 \% ; * * *=$ significant at $1 \%$

This suggests that with Kasena Nankana District, given its coefficient as 0.320 holding all other variables constant, respondents from the Kasena Nankana District spend 32\% per week on basic needs more than respondents from Talensi Nabdan, Bongo and Builsa Districts which are the reference categories. The coefficient of Bawku West District is 0.604, implying that respondents from the Bawku West District also spend on the average 60.4\% per week on basic needs more than those from Talensi Nabdan, Bongo and Builsa Districts which are the reference categories. Even though respondents in the district have a lower probability of receiving a loan at least three times from an MFI than the other Districts they have the highest weekly expenditure. Also respondents from the Bawku West District spend about 
28.4\% per week more than their counterparts in the Kasena Nankana District. As has been stated earlier, both the Kasena Nankana and Bawku West districts have very vibrant market centres with patronage from neighbouring country, Burkina Faso.

The results also show that the coefficient of receiving a loan at least 3 times from an MFI is 0.566. By this therefore, beneficiaries who have received loans at least 3 times from an MFI spend on the average $57 \%$ per week on basic needs more than those who have received loans at most two times from MFIs in the Upper East Region of Ghana holding all other factors constant. This means that receiving a loan at least 3 times from an MFI has the effect of increasing weekly expenditure on basic needs on the average by $57 \%$.

The age coefficient is given as 0.0469, suggesting that if one's age increases by an additional year, then weekly expenditure will also increase on the average by $5 \%$. Thus as one ages overtime, she becomes more experienced and skilful in her economic activity and this could increase her efficiency level and for that matter higher earnings which is ultimately translated into increased expenditure per week. However, beyond the age of 44 years weekly expenditure declines with an increase in age given the fact that the coefficient of age-squared $(-0.000529)$ is negative. By implication as one ages over and above the age of 43 years, her capacity to garner more resources for consumption begins to wane, thus her weekly consumption level reduces marginally by 0.000556 with an additional increase in age.

The amount of profit per month is also positively associated with weekly expenditure given its coefficient of 0.00125 . Thus, if profit increases by one Cedis (Gh\&1) per month then weekly expenditure will increase by $0.13 \%$. As the respondents make more profits from their agro-processing business they spend part of these profits on basic needs and for that matter driving them out of poverty.

Also the number of income generating activities engaged in by the respondent has a positive impact on weekly expenditure given its coefficient of 0.0482. By implication if the number of income generating activities increase by one, then weekly consumption expenditure will also increase on the average by about $5 \%$.

Again, both primary school and Post Secondary school categories of the level of education have positive impacts on weekly expenditure and for that matter poverty reduction given their coefficients as 0.137 and 0.509 respectively. Thus, respondents with primary school and Post Secondary school education spend on the average $14 \%$ and $51 \%$ respectively higher per week than their counterparts who have no formal education. This suggests that, may be those with primary and post secondary school education are better able to manage their agro-processing businesses very well and so make more money which enables them to spend more than those with no education. Considering the fact that respondents with Post Secondary school education spend about $51 \%$ more than those with no education, it is evident that for MF to be able work well for beneficiaries in terms of poverty reduction, then they need to have an appreciable level of education so as to be able to take advantage of any business opportunity.

The coefficient of the number of dependants in a respondent's household is given as 0.0350 . 
This shows that it has a positive impact on weekly expenditure (poverty reduction). Thus as the number of dependants in the household increases by one, weekly expenditure increases on the average by about $3.5 \%$.

The bottom part of the Table shows that the coefficients of rho $(\rho)$, sigma $(\sigma)$ and lambda or selection hazard $(\lambda)-0.385,0.506$ and -0.195 respectively are all significant. $\rho \sigma_{\varepsilon}=\lambda$, determines if selection bias exists or not, once $\lambda$ is significantly different from zero, then it can be concluded that selection bias exists in the sample and has been corrected for. Also the negative sign of the coefficient of $\lambda$ shows that, OLS estimation of the impact of receiving a loan at least 3 times from an MF will be bias downwards.

Table 4: Two-sample t-test with unequal variances for log of weekly Consumption expenditure for receiving microfinance at least three times

\begin{tabular}{|c|c|c|c|c|}
\hline Variable & & & Mean & Std. Dev. \\
\hline Lwkexpend & & & 3.138 & 0.339 \\
\hline Nlwkexpend & & & 2.94 & 0.334 \\
\hline diff. & & & 0.202 & 0.157 \\
\hline $\begin{array}{l}\mathrm{H}_{0}: \text { diff }=0 ; \\
\text { Satterthwaite's degrees } \\
\text { of freedom }\end{array}$ & $\mathrm{t}=$ & $\begin{array}{l}8.8656 \\
871.805\end{array}$ & & \\
\hline Obs. & & 437 & & \\
\hline
\end{tabular}

Source: Computed from field Survey data, (2011)

Note: $\quad$ diff $=$ mean $($ lwkexpend $)-$ mean $($ nlwkexpend $)$

Table 4 shows the t-test of the significance of the difference of weekly consumption expenditure for receiving MFI loans at least three times and those who received MFI loans less than three times estimated at the means contingent on all the variables that are significant in explaining weekly consumption expenditure. These variables are, Kasena Nankana District, Bawku west District, age of the respondent, age-squared, number of dependants in household, amount of profit, number of income generating activities, Primary school, Post Secondary school and receiving loans at least 3 times.

Thus, lwkexpend is the mean of log of weekly consumption expenditure for respondents who have received loans at least 3 times contingent on the above variables, nlwkexpend is the mean of log of weekly consumption expenditure for respondents who have received loans at most 2 times contingent on the above variables, while diff is the difference between lwkexpend and nlwkexpend. The mean weekly consumption expenditure for respondents who have received loans at least 3 times is 3.138, while that of respondents who have received loans at most 2 times is 2.936, contingent on all the statistically significant variables. This means that respondents who have received loans at least 3 times spent about GH\$23.05 per week on basic needs while respondents who have received loans at most 2 times spend Gh\$18.84 per week on basic needs contingent on the statistically significant variables.

However the difference between the mean weekly consumption expenditure for the two 
groups is 0.2018 . The t-test of the null $\left(\mathrm{H}_{0}\right)$ that the difference in weekly expenditure for the two groups is equal to zero is rejected given the t-test value of 8.8656. This indicates that respondents who have received loans at least 3 times spend GH\$1.22 more per week on basic needs than respondents who have received loans at most 2 times. Using the expenditure of those who received loans at most 2 times as a counterfactual outcome for respondents who have received loans at least 3 times therefore, it can be said that respondents who received loans at least 3 times would have been spending Gh\$18.84 per week if they had not received loans at least 3 times from the MFI; but they now spend GH\$23.05 per week, that is GH\$1.22 per week more. This suggests that receiving loans at least 3 times from MFIs has increased beneficiaries’ weekly expenditure by GH\$1.22.

As a robust check, the threshold was increased to receiving loans at least 4 times. Table 5 shows the results of the treatment effect estimation of impact of receiving MFI loans at least four times on log of weekly consumption expenditure.

Table 5: Results of impact of receiving loans at least four times from MFIs (dependent variable: weekly consumption expenditure)

\begin{tabular}{|c|c|c|}
\hline Variables & Coefficients & Standard errors \\
\hline Kasena Nankana $\quad$ District $(1 / 0)$ & $0.348 * * *$ & 0.0718 \\
\hline Bawku west District (1/0) & $0.619 * * *$ & 0.0688 \\
\hline Number of people in household & -0.00140 & 0.00889 \\
\hline Dependants in household & $0.0273^{* *}$ & 0.0131 \\
\hline Initial Savings & 0.000107 & 0.000205 \\
\hline Number of borrowing sources & -0.0213 & 0.0676 \\
\hline Amount of profit & $0.00149 * *$ & 0.000601 \\
\hline Age in years & $0.0510 * * *$ & 0.0139 \\
\hline \multirow[t]{2}{*}{ Age-squared } & & 0.000154 \\
\hline & $-0.000570 * * *$ & \\
\hline Primary school(1/0) & $0.168^{* *}$ & 0.0655 \\
\hline JSS/Middle school(1/0) & 0.0981 & 0.0782 \\
\hline SSS/Secondary school(1/0) & -0.110 & 0.111 \\
\hline Post Secondary school(1/0) & $0.546^{*}$ & 0.306 \\
\hline No. of income generating activities & 0.0341 & 0.0218 \\
\hline Value of physical assets & $2.55 \mathrm{e}-05$ & $2.84 \mathrm{e}-05$ \\
\hline Received loans at least four times $(1 / 0)$ & $0.879 * * *$ & 0.183 \\
\hline Constant & $1.413 * * *$ & 0.301 \\
\hline athrho & $-0.590 * * *$ & 0.223 \\
\hline lnsigma & $-0.683^{* * *}$ & 0.0370 \\
\hline Lambda & $-0.137 * * *$ & 0.0428 \\
\hline Observations & 437 & \\
\hline
\end{tabular}

Source: Computed from field Survey data, (2011)

Note: $*=$ significant at $10 \% ; * *=$ significant at $5 \%$; ***=significant $1 \%$

The results show that the coefficient of receiving a loan at least 4 times from an MFI is 0.879 . 
By this therefore beneficiaries who have received loans at least 4times from an MFI spend on the average $88 \%$ per week on basic needs more than those who have received loans at most three times from MFIs in the Upper East Region of Ghana holding all other factors constant. This means that receiving a loan at least 4 times from an MFI has the effect of increasing weekly expenditure on basic needs on the average by $88 \%$.

Table 6 shows the results of the test of the significance of the difference in weekly expenditure of respondents who have received loans at least 4 times (lwkexpend) and those who have received loans at most 3 times (nlwkexpend).

Table 6: Two-sample t-test with unequal variances for log of weekly Consumption expenditure for receiving microfinance at least four times

\begin{tabular}{|c|c|c|c|}
\hline Variable & & Mean & Std. Dev. \\
\hline lwkexpend & & 3.233 & 0.349 \\
\hline nlwkexpend & & 2.952 & 0.332 \\
\hline diff. & & 0.281 & 0.236 \\
\hline $\mathrm{H}_{0}: \operatorname{diff}=0$ & $\mathrm{t}=12.197$ & & \\
\hline $\begin{array}{l}\text { Satterthwaite's degrees of } \\
\text { freedom }\end{array}$ & 869.861 & & \\
\hline Obs. & 437 & & \\
\hline
\end{tabular}

Source: Computed from field Survey data, (2011)

Note: $\operatorname{diff}=$ mean(lwkexpend $)$ - mean(nlwkexpend)

The results indicated that the difference between the mean weekly consumption expenditure for the two groups is 0.281 (28.1\%). The t-test of the null $\left(\mathrm{H}_{0}\right)$ that the difference in weekly consumption expenditure for the two groups is equal to zero is rejected given the t-test value of 12.1966. This indicates that respondents who have received loans at least 4 times spend GH\$1.32 more per week on basic needs than respondents who have received loans at most 3 times. Using the consumption expenditure of those who received loans at most 3 times as a counterfactual outcome for respondents who have received loans at least 4 times therefore, it can be said that respondents who received loans at least 4 times would have been spending GH\$19.14 per week if they had not received loans at least 4 times from the MFI; but they now spend GH\$25.35 per week, that is GH\$1.32 per week more. This suggests that receiving loans at least 4 times from MFIs has increased beneficiaries' weekly consumption expenditure by GH\$1.32.

These findings are consistent with the theory on microfinance which indicates that continued access to credit and the process of increased investment increases income yet further. The theory suggested that as this cycle is continually repeated with successive loans the poor borrower will gradually climb out of poverty (Khan, 2008). 


\section{Conclusions and Policy Recommendations}

The study sought to evaluate the impact of the number of times beneficiaries receive MFI loans on beneficiaries' welfare. Using the treatment effect model for the estimation, the results indicated that beneficiaries who received MFI loans three or more times have about 57 percent consumption expenditure per week on basic needs more than beneficiaries who received MFI loans less than three times. Again weekly consumption expenditure was 88 percent more for beneficiaries who received loans from MFIs loans four or more times than those who received loans less than four times.

Thus it is concluded that receiving MFI loans multiple times has a positive impact on beneficiaries' household consumption expenditure and by extension poverty reduction. It is also concluded that impact heterogeneity exist among the borrowers based on the number of times one borrows from an MFI. It is therefore recommended that MFI should lend out to clients as many times as possible as long as the clients are able to repay.

\section{References}

Akpalu, W., Alnaa, S. E., \& Aglobitse, P. B. (2012). Access to microfinance and intra household business decision making: Implication for efficiency of female owned enterprises in Ghana. Journal of Socio-Economics, 41(5), 513-518. http://dx.doi.org/10.1016/j.socec.2012.04.020

Annim, S. K., \& Alnaa, S. E. (2013). Access to microfinance by rural women: Implications for poverty reduction in rural households in Ghana. Research in Applied Economics, 5(2), 19-41. http://dx.doi.org/10.5296/rae.v5i2.2974

Banerjee, A., Duflo E., Glennerster R., \& Kinnan C. (2009). The miracle of Microfinance? Evidence from a randomised evaluation. Cambridge, MA: Department of Economics, MIT, Mimeo.

Consultative Group to Assist the Poor (CGAP) (2008). Who is funding Microfinance? Results of the First Global Survey of Funders Microfinance Portfolio. Washington DC: CGAP/World Bank Group.

Diagne, A., \& Zeller, M. (2001). Access to credit and its impact in Malawi. Research report No. 116 Washington, D.C., USA: International Food Policy Research Institute (IFPRI).

Feigenberg, B., Field, E. M., \& Pande, R. (2010). Building social capital through microfinance, Kennedy School, Harvard University, Cambridge. http://dx.doi.org/10.3386/w16018

Ghalib, A. K., Malki, I., \& Imai, K. S. (2011). Impact of microfinance and its role in easing poverty of rural households: Estimation from Pakistan. Discussion paper series no. DP2011-28, Kobe University, Japan, Research Institute for Economics and Business Administration. 
Ghana Statistical Service (2008). Ghana living Standard survey: Report of five round (GLSS5). Accra: Author.

Gobezie, G., \& Garber, C. (2007). Impact assessment of the microfinance programme in Amhara Region of Ethiopia. Paper presented at International Conference on Rural Finance Research: Moving Results into Policies 19-21 March 2007 FAO Headquarters, Rome Italy.

Greene, W. H. (2003). Econometric analysis (5th ed.). Upper Saddle River, NJ: Prentice-Hall.

Heckman, J. J., \& Vytlacil, E. (2005). Structural equations, treatment effects, and econometric policy evaluation. Econometrica, 73(3), 669-738. http://dx.doi.org/10.1111/j.1468-0262.2005.00594.x

IFAD. (2009). Rural poverty in Ghana. Retrieved February 12, 2010, from http://www.ruralpovertyportal.org/web/guest/country/home/tags/ghana

Imai, K. S., \& Azam, S. (2010). Does microfinance reduce poverty in Bangladesh? New evidence from household panel data. Discussion Paper Series, Research Institute for Economics and Business Administration, Japan: Kobe University. http://dx.doi.org/10.1016/j.worlddev.2010.04.006

Imai, K. S., Arun, T., \& Annim, S. K. (2010). Microfinance and household poverty reduction: New evidence from India. World Development, 38(12), 1760-1774.

Karlan, D. \& Zinman J. (2009). Expanding credit access: Using randomised supply decisions to estimate the impacts, New Haven, Financial Access Initiative.

Khan, A. A. (2008). Islamic microfinance: Theory, policy and practice. Birmingham: Islamic Relief Worldwide. Retrieved December 13, 2011, from http://www.islamic-relief.com

Khandker, S. R. (2005). Microfinance and poverty: Evidence using panel data from Bangladesh. The World Bank Economic Review, 19(2), 263-286. http://dx.doi.org/10.1093/wber/lhi008

Littlefield, E., Murduch, J., \& Hashemi, S. (2003). Is microfinance an effective strategy to reach the millennium development goals? Retrieved November 23, 2009, from http://ifmr.ac.in/cmf/wp-content/uploads/2007/06/mf-mdgs-morduch.pdf

Marguerite, R. (2001). The microfinance revolution: Sustainable finance for the poor. World Bank. Washington.

Morduch, J., \& Haley, B. (2002) Analysis of the effects of microfinance on poverty reduction. New York University Wagner Working Paper No. 1014. Retrieved November 10, 2009, from http://www.nyu.edu/wagner/public_html/cgibin/workingPapers/wp1014.pdf

Navajas, S. et al. (2000). Microcredit and the poorest of the poor: Theory and evidence from Bolivia. World Development, 333-346. http://dx.doi.org/10.1016/S0305-750X(99)00121-7 


\section{Macrothink}

Research in Applied Economics

ISSN 1948-5433 2013, Vol. 5, No. 3

Okurut, F. N., Banga, M., \& Mukungu, A. (2004). Microfinance and poverty reduction in Uganda: Achievements and challenges. Research series No. 41. Uganda, Kampala: Makerere University

Remenyi, J., \& Quinones, B. (2000). Microfinance and poverty alleviation: Case studies from Asia and the Pacific. New York: Asia Development Bank

Note

Note 1. These include financial NGOs

\section{Copyright Disclaimer}

Copyright reserved by the author(s).

This article is an open-access article distributed under the terms and conditions of the Creative Commons Attribution license (http://creativecommons.org/licenses/by/3.0/). 